\title{
Further Vocational Education as Projected in Innovation Development of Adult Education
}

\section{Galina Ignatieva}

\author{
Doctor of Pedagogical Sciences, Professor Head of the Department of Pedagogy and \\ Andragogy of Nizhny Novgorod Education Development Institute; gaididakt@rambler.ru
}

\section{Oksana Tulupova}

Candidate of Pedagogical Sciences, Associate Professor at the Department of Pedagogy and Andragogy of Nizhny Novgorod Education Development Institute; oksana-nnov@yandex.ru

\section{Doi:10.5901/mjss.2015.v6n6s5p178}

\begin{abstract}
The paper suggests a way of solving the key problem of further vocational education which is registered in the controversy between the production understanding of vocational education and the active nature of human life as such in the anthropological view. The targets of the research conducted in the logic of concept genesis of the idea to build an anthropological concept of further vocational education of pedagogues are related to constructing a conceptual model, developing the content of this concept and forms for its implementation as a cultural and educational structure of a new type. As research methods, the following tools of institutional approach in education are employed: the analysis of condition of personnel potential, construction of new forms, methods and content of training the managerial and pedagogical staff in the systems of "education - science - practice" cooperation; the development and use of educational, managerial, social and economic, information and other humanitarian technologies as mechanisms for further vocational education to function and develop; the method of layered modeling of the new educational institution. The characteristics to the layered differentiated model of the further vocational education complex as a cultural and educational institution for raising a new type professional, the "Project and network institute of innovation education" is given. The paper outlines the technology of "corporate educational co-working center" as a generic technological framework for implementing the layered model. This is an event-based educational technology of rearing the new professionals which integrates the "blended learning" technique and the "action learning" one. The conceptual model of further vocational education for pedagogues suggested by us is in line with the world conceptual trends of development of adult education. The nearest prospect of the research is seen in building the new conceptual structures of developing the further vocational education and in passing to activity-based forms of transforming this educational reality.
\end{abstract}

Keywords: further vocational education, adult education, continuous education, anthropological approach, innovation education.

\section{Introduction}

The paradigmal shift in the orientations system of the contemporary adult education makes the further vocational education system face essentially new theoretical problems. The most important ones of them center around the problem which is perhaps the most vital today - that of development of an adult learner.

The name of our paper refers to two categorical word combinations: "further vocational education" and "adult education". The categories are marginal for various branches of the contemporary humanitarian scientific knowledge associated with education and the historical perspective of their development. The relevance of studying these categories within a broad theoretical and methodological context is explained first of all by the very logic of social development which is characterized by globalization of social processes; new telecommunication and information technologies; social and economic differentiation dynamics; transformation phenomena in various spheres of the Russian society etc.

At present, the sphere of further vocational education for pedagogues exists in controversial processes. On the one hand, "lifelong education" is an inherent value and a condition of human development in all his incarnations forming the fullness and integrity of human reality. On the other hand, the predicate "vocational" points to a special thingness of education which obliges us to perceive the further vocational system as a supplier of staff for all social practices.

In this dichotomy, further vocational education has been unable to identify itself within the space of continuous education so far, which is promoted by so-called "production thinking" rooted in the professionals' consciousness. It has acquired its predominant meaning as the main ontological and organizational and technical form of ideas about the 
vocational education having generated a huge lot of scientific and pedagogical approaches (e.g. competency-based one), empirical ideas about the practice of vocational education. The pedagogical community is plunged into them entirely, keeping to organize all forms of further vocational education according to the "production" principle. On the other hand, further vocational education is related to human reality, to problems of its essence and fullness, to anthropological (and not production one in nature) meaning, contained in the consistency of human development in ontogenesis; to conditions of human growth and rise in educational processes; and to realias of social life.

The question is about being of further vocational education watched in dynamics, i.e. in acts of its development. In essence, during further vocational education, a continuous process of professiogenesis, professional "updating" of the humanity. The being of further vocational education is the being of a human in his professional development acts which is embodied in certain forms of professional practices.

Thus, we have approached wording of main problems range of further vocational education, i.e. registering the controversy between the production understanding of vocational education and the essentially active nature of human life in anthropological projection. This controversy can and has to be solved within integration and coupling of two directions: a) vocational training up to the requirements of socium and b) vocational development of a human as a value and a goal.

\section{Goal and Objectives of the Research}

The necessity of resolving the controversy between innovation processes development in education and the low sensitivity of the existing further vocational education system to problems and opportunities of "raising" a new type professional has determined the topicality of development of a principally new conceptual model of further vocational education. It is based on the ideas of education anthropology, its world outlook (value and meaning), theoretical and methodological (instrumental) grounds characterizing the education from the standpoint of the human reality rising in it in its entirety (Slobodchikov, 2009).

The grounds have found their reflection in four mutually conditioned aspects. The first aspect is conditioned by the growing significance of the idea of human versatility and professionalism factor in the sphere of education as a multiaspect and polycultural phenomenon. The second aspect is related with using the projecting method as a mechanism for pedagogues' professional development. The third aspect consists in understanding the category of innovation content of pedagogues' further vocational education. The fourth aspect is manifested in building a new system of meaning and organizational-managerial links of further training system and organization of a new type professional community which implements the principles of development and self-development.

The idea of creating an anthropological concept of pedagogues' further vocational education has covered a certain way of its development which we characterize as conceptogenesis meaning by it a theoretical and practical description of the origin of the developing object. A starting point was to organize a project experiment in the system of education of Nizhny Novgorod Region. The experiment involved a specific method of interdisciplinary research which allows building a system of experimental activity as a space of social-cultural forms of education implementing certain organizational projects. During performing the project experiment at the chair of pedagogics and andragogics of Nizhny Novgorod education development institute, the concept of activity-based content of the professional development of pedagogues in the system of further vocational education was developed and experimentally approbated. The concept was built on the interrelation of the new content type - activity-based education content which is the main condition or the leading factor of pedagogues' professional development - and a special technology of mastering it - self-learning organization (Ignatieva, 2005). This concept became the methodological basis for creating a complex of further vocational educational programs oriented to the rise of pedagogues-innovators.

The next landmark in conceptogenesis of the idea about an anthropological concept of further vocational education of pedagogues was determined by the regional network experimental educational project "Nizhny Novgorod innovation school" launched in 2008 in Nizhny Novgorod Region. Within the activity of the project and network community of Nizhny Novgorod schools, "raising of innovations" was carried out, i.e. the innovation practice was propagated in the regional educational space through adapting, developing various elements of innovation development or innovation system as a whole in the own conditions of the educational institutions.

During implementation of the project, the problem of innovation development of the regional education system in conditions of meeting the key requirements of state education policy was clearly outlined: corporate education has to be created and the information about novelties and dissemination of results of innovations has to be exchanged promptly. The problem was worded as follows: "How to create a new type of educational institution as a space for co-organization of innovation activity subjects' professional positions from the standpoint of project and network paradigm?".

The project and network innovation education institute was determined to be such a new educational institution as 
a top form of spatial co-organization of innovation activity subjects' professional positions. Creation and organization of activity thereof became a strategic goal of the eponymous federal innovation platform of the RF Ministry of education and science (Barmin \& Ignatieva, 2012).

This paper describes the today's stage in the activity of the project and network institute associated with building the conceptual model, developing the content of anthropological concept of pedagogues' further vocational education and forms of implementation of the former as a new type cultural and educational structure.

\section{Research Methods}

We believe that in developing the anthropological concept of further vocational education the institutional approach has a high productivity. First of all, what is meant is understanding of "rules of the game" in a situation of numerous institutions co-existing, because they can come into mutual controversies when interacting, complementing and conditioning each other, so the controversies have to be eliminated. Secondly, the institutional environment should be viewed in the characteristics of density and hierarchical structure, which can also be a factor of influence on the efficiency of further vocational education system.

In connection to this, we have singled out two crucial aspects when building the new institution within the further vocational education system.

The first one is the necessity to analyze the condition of personnel potential, to build new forms, methods and content for training the managerial and pedagogical personnel in the systems of "education - science - practice" cooperation, which will allow accumulating and mutually address the potential of vocational education sphere subjects. Here the objective of ordering a new professional arises. So, in order to keep the positions in the social development dynamics getting ever more complicated, a compulsory passage to project work forms is expected. In the project experiment conditions, we discuss and develop a new type of scientific, educational and technological patterns as a "major" innovation development project for further vocational education. Moreover, we are trying to envelop everything which was said at the stage of setting standards for innovation into a certain technological form of a "new education institution". Meanwhile, a compulsory general condition for building thereof (and, therefore, of all interaction kinds) is an purposed project and network cooperation within an integral system consisting of various activities: practice-oriented and fundamental science, innovation type design and engineering developments, network structures of organization and management etc.

The second crucial aspect involves developing and using the educational, managerial, social and economic, information and other humanitarian technologies as mechanisms for further vocational education to function and develop. With regard to this, such criterial base of assessing its efficiency is essential which would be able to ensure real conditions for subjects' resources co-organization in the system of "production - science - education" cooperation, up to individual interactions of institutions and organizations, on the one hand, and the entire social infrastructure, on the other hand.

When discussing the content of the anthropological conceptual model of pedagogues' further vocational education and the forms of implementation of the former as a cultural and educational structure, we used the method of layered modeling for the new educational institution. This kind of modeling is rooted in cybernetics; based on information technologies, it allows revealing and systemizing all elements of a system, its links, structure and subsystems in a formalized kind, as well as identifying the closest external environment thereof (Privetkin, Privetkina, 2008).

\section{Results}

Let us represent the complex of further vocational education in a layered diagram of its composition and bordering structures.

Further vocational education is habitually represented in the following forms: improvement, further training, vocational re-training (mastering a new vocational activity kind or obtaining an additional qualification), on-the-job training. The principle of such differentiation is only the complexity of the "study material" and academic process organization, yet it includes components which are identical in essence as they are oriented to the "uniform goal" being in line with social requirements of the social production available while existing beyond the scope of a subject's professional or personal self-determination. At the same time, this does not mean any inferiority of the content of one layer versus another one. Each layer is independent, codified, and it possesses the opportunities for development and connection with other layers. Given such variability of life or professional conditions of our reality, it makes no sense either to refuse reasonable practicality requirements. 
Improvement is making the activity better up to the new samples thereof which emerge in the culture. This is a form (process) of complementing the professional activity of a specialist with new elements thereof in a situation when the activity has been found to fail to meet the new requirements of development processes in scientific and technical, humanitarian areas of social practice taking place simultaneously. With regard to this, having once improved his activity, a worker of any professional sphere has to repeatedly turn to this kind of further education subsequently - and up to the end of his career. However, we would call it not quite "further education" but rather "supplementing (or catching up) training".

In enhancing one's professional qualification, the attitude of supplementing the professionalism with new knowledge, techniques and means of activity is actually preserved in the discrete process of social norms mastering. Enhancing the professionalism level up to mastering the systemic knowledge and abilities in the complex of notions mostly takes place already in mastering the professional competencies, not excluding the development of the ability to build and implement one's own activity in the initial conditions, to design and modify it.

Professional development. Unlike the improvement and enhancing the professional qualification, this is a continuous process occurring in the ontogenesis of human socialization and aimed at adopting various aspects of the labor world, in particular, professional roles, personal motivation flexibility, professional knowledge and skills. The main driving force of professional development is an individual's seeking to be integrated into the social context on the basis of identification with social groups and institutions. It is already about not only professional suitability for certain professional activity conditions but rather about acquiring a complex of abilities that allow one to adjust (change and format) one's professional life. During the professional development, new abilities emerge: the ability to work with education and development processes in the "educational knowledge" logic, to master the professional activity development means. Having a similar structure, further vocational education makes the methods of thinking underlying various knowledge systems visible; it allows creating preconditions for moving to an essentially new activity content, self-identifying in professionally significant situations, and building the self-education programs. Within this approach, the professional growth potential of a specialist is unlimited.

The bordering structures of pedagogues' further vocational education complex are manifested in specific positions. The first one is methodological and is aimed at all kinds of works that are essential for developing the continuous adult education. The second one comprises the following: a) groups of transforming positions aimed (by definition) at developing the systems of general and further vocational education (which is reflected in preliminary program works and described below), in particular - using the project culture (design itself, programming and planning) aimed at real transformation of further vocational education practice; b) a group of provision positions aimed at maintaining the functioning within the cultural limits.

With the high speed of change in today's society and increasing complexity of professional tasks, the contemporary pedagogues have to possess crucially new knowledge, abilities and skills ensuring them an opportunity to form such qualities in their pupils according to their personal and age-related particularities as to make them sought-for in the new world. These are systemic thinking, the ability to manage projects and processes, to work with various requests, with teams, groups and individuals, the ability to quickly respond to change, to distribute resources and manage the traffic thereof. Each of these universal abilities makes up the essence of a certain pedagogical position. The developed by us anthropological concept of development for pedagogues' further vocational education includes the characteristics of the following professional positions ensuring the achievement of cultural and educational, social effects required by the society: 1) moderator of solving the study and cognitive, study and practical tasks; 2) developer of individual educational paths; 3) tutor; 4) navigator of educational events; 5) projects (research) mentor; 6) social practices coordinator; 7) play techniques expert; 8) anthropotechnologist; 9) evolution consultant; 10) the children's "image of the future" expert ${ }^{1}$.

We believe these professional positions making up the basis of the cultural and educational complex bordering structure determine the character of educational technology in the further vocational education system. The educational technology associated with mastering this or that position, with its central idea about human communities development that sets the leading reference points of educational interactions is put by a pedagogue into the basis of the educational activity design.

The generic technological framework of further vocational education is envisaged by us as an event-based educational technology of activity-related type. Such form of pedagogues' professional positions formation program implementation in conditions of further vocational education as "blended learning" is the most relevant to the requirements. It is based on systemic approach to educational process organization which is expressed in a combination of face-to-face and e-learning. The blended learning model is based on a flexible combination of the following

\footnotetext{
${ }^{1}$ http://www. niro.nnov.ru/?id=23832
} 
components: the component of the traditional direct personal interaction of educational activity subjects; the component of interactive communication conditioned by the computer telecommunication technologies and digital information and educational online resources; the component of self-education.

The "blended learning" model is a shared organization framework for implementing the additional vocational program of modular qualification courses which is represented by the following formats: supra-subject invariant module online learning (online collaborative learning); varied modules - face-to-face learning and independent learning (selfstudy learning) with remote consulting; training and design module - face-to-face, individual and group designing (collaboration) using the Internet-based communication.

The technological implementation vector for the additional vocational program oriented to forming a new professionalism in pedagogues is set by "action learning" - a type of learning to which learning within project groups doing something real and definite is central, as well as in which focus groups are organized that imply a project group work specialist's dialogue with the group for identifying the learners' needs and solving the shared problems. Within the project experiment, we introduce further techniques of supportive questions, logical diagrams and organization of methodological learning reflexion (Mitina, 2005) into the classical formula of action learning technology given by its authors, R. Revans (UK) and M. Marquardt (USA).

Such understanding of the event-based educational technology of raising the new professionals poses most difficult tasks of holding the entire massif of innovations to the further vocational education system. Reconsideration of the role and objectives of institutional change in reforming the further vocational education has led us to the necessity of development the project or technology "corporate educational co-working center" within the federal innovation platform "Project and network institute of innovation education".

This technology represents: 1 ) a form of organizing works on changing the thinking and activity of specialists teams and groups who solve the practical tasks in a certain sphere of professional activity (the education sphere, in our case); 2) a professional art of transforming the adults according to the "do it yourself" principle; 3 ) a way of translating the space of work (doing) into the space of learning and mastering the method of doing - "It is only by doing that you can learn something". The technology is based on the following principles:

The principle of practicality: relying on accumulation and transfer of experience. The use of this principle is essential where the task of people's step-by-step change is solved. It is opposed to the principle of "culture translation" which implies not changing the people but filling them with "theoretical" knowledge accumulated by the humanity;

The principle of team organization: efficient learning is only possible in an appropriate working environment. Learning is a function of the rules of behavior and communication in a group where one gets included. Purposed training has to be built as a specially organized communicative space.

Disciplinary approach and the "learner" position mean forming an ability to subject oneself to the standard of thinking (action) and to follow it rigorously. The ability to consciously subject oneself to the standard of thought is not set by tools of guiding - subordinating - but is brought up and mastered in a business "absorbing and involving" one. It is possible to get activity-based (i.e. genuine) disciplinary training by taking the most efficient life position - that of a "learner" - independently and, as a rule, outside the traditional education sphere institutions which are mainly designed as enterprises for transferring the subject knowledge systems to the learners.

What concerns the content of the "corporate educational co-working center", it is project and analytical sessions that act as the "bearing framework". All the remaining activities are anyway secured on the framework. Project and analytical sessions are design platforms where people can get an experience of building a new educational practice during individual or joint team project works, presentations thereof, joint expertise. The topics of project and analytical sessions and the participants list are determined by the management of the co-working center for the current year, proceeding from problems and objectives that are or will be relevant for the education sphere currently or in the nearest future.

At the sessions, work takes place according to the standard procedure: solving analytical tasks - learning the technologies of building a new educational practice (design, programming, strategizing etc.) - development of own projects - standards and activity-based expertise. The "problem material" is the same for all participants and is considered from various aspects (positions) and at various speed (depending on the specific nature of each participant's initial situation as well as their competence). As a result, the problem situation gets "layered" into tasks being solved individual projects. Each participant obtains his own unique result as the output. The entire team works in an open platform in conditions of organized team communication and "participative" planning. With regard to this, everyone can be a consultant on this or that question within their competence. 


\section{Discussion}

With further vocational education being an institutional form of adult education, and given the Russian vocational education system starting to orient to the Western standards and foreign technologies implementation in the recent years, we deemed it important to look at our findings in the light of the leading conceptual trends of developing and understanding the essence of adult education abroad as well as possible prospects of their influence on innovation development further vocational education.

Just like any other social practice, further vocational education should be considered as an independent system of activity, with its own ideology, values, program attitudes, qualified pedagogical personnel, organizational structure consisting of various activity types (management, design, scientific, methodical activity), and its own mechanisms of functioning and development.

According to A.M. Mitina, the foreign sources give the classical interpretation of "further adult education" category in the following binary opposition depending on self-determination of an adult: additivity - supplementing the basic education with partially adding content which is also compensating or correcting; complementarity - replenishment of the educational content available with new knowledge that is vital for an adult person (Mitina, 2005).

Abroad, further adult education is developed within the framework of consolidating the complementary constituent in the following directions: 1) increasing the diversity of the content, kinds and forms of educational services; 2) expanding the age boundaries for getting an education; 3) increasing the importance of higher education; 4) creating corporate universities "within" large companies; 5) paying more attention to educational needs of older people, ones of the "third" and "fourth" age; 6) placing the responsibility from the state and companies to a person - an adult person's becoming responsible for one's own education etc. (Kravchenko, 2012).

From the standpoint of combining the social and political interests in education with the economical ones, in practice the adult education is brought into life in the developed countries at the three main levels - innovation, normative (catching up) and social ones. The first one involves learning high-tech knowledge and skills that ensure upgrade transformations of the economy (at the macro level) or enhance the competitiveness of a certain organization (at the micro level). The second level is normative (catching up) education the content of which is mainly composed by stable and widespread knowledge. The third level is associated with further, adapting learning which has mainly social effect such as supporting the adults who have faced risks.

It should be emphasized that this stratification is maintained both on the whole at the scale of the entire society and within individual professional communities. So, the first level in further vocational education is represented by the innovation educational programs for so-called "professional elite"; the second level is made up by traditional programs aimed at keeping up the level of specialists' professional competence in a condition ensuring a stable functioning of an economy or social sphere branch. The third level involves support for specialists having varied professional difficulties, including ones associated with the phenomenon of "professional burnout".

Against the background of dynamic transformation processes of the social development, the research priorities in the sphere of adult education are increasingly focused around the "communicative learning" models which are implemented along the lines of informal people's communication (Habermas, 1987) or "transformative learning" ones. The latter are associated with the spread of new forms of learning and knowledge, including the experimental and implicit (daily, commonplace) knowledge, for obtaining which the programs of educational tourism, club work, museum excursion programs and the like are used that actually erase the border between institutionally organized learning and leisure pastime (Mezirov, 2000).

It is the ideas of "transformative learning" that are the subject of a curious scientific discussion taking place on the pages of the leading American scientific journals (Adult Education) specialized in studying the issues of adult education in the recent years. In particular, they discuss questions about transformative learning and practice-based learning being related (Newman, 2014), particularities of adult education process which is generated when facing unambiguousness that in its turn occurs due to changing reality (Nicolaides, 2015), and educational projects for adults in the focus of social justice (Stein, 2014).

Generalizing and typologizing the models of Russian and West European further vocational education to the utmost, A.M. Mitina has demonstrated that among the leading foreign concepts (continued education, continued vocational education, recurrent education, further education, informal education, communal education, education in the form of "organization being educated", and one in the form of "society being educated") it is the concept of "society being educated" which describes the educational situation of the society as a whole determining the essential links in social and economic infrastructure of today's Western countries that is the integrative kind of adult education (Mitina, 2005).

Among the main problems of foreign research in continuous adult education, the priority ones for studying are the 
cognitive motivation problems, ones of creating an open educational environment, developing the andragogical education model, typology of adult cognitive styles, working out the pedagogical technologies oriented to raising the capacities for reflexion and self-development, transformation of personal and life experience into professional practice, enhancing the professional competencies etc. (Kravchenko, 2012).

The foreign literature on philosophy and psychology links the innovation orientation of adult education first of all to the creative character of life activity of the human himself. Researchers studying the problems of further adult education development point out the formation of an open educational environment as the priority trend. Recently, the creation of efficient teaching environments has become the subject of lively discussion - ones where the opportunity of self-study for people of all ages can be ensured. One of the promising models of independently organized learning is the " Pedandragogy" model which synthesizes in itself the main elements of pedagogics and andragogics and is suggested by the American researchers as one of the efficient ways for developing the human capital (Samaroo \& Cooper \& Green, 2013).

Within the theoretical analysis of adult education, the following conceptual trends and adult education models associated with them have to be highlighted: the sociological concept where the accent is on mutual influence of the social structure of reality and learning, with the latter viewed as a method of changing the surrounding world; the psychological concept where learning is considered to be a major factor of an adult's mental development; the phenomenological concept which takes into account the influence of social and cultural environment on the study process, on the one hand, and the mental and physiological particularities of adult learners, on the other hand. The models and methods of teaching the adults are completely in line with these concepts, in particular: the traditional didactic one (demonstration, lecture), the problem and search one (guided discussion method, mentorship), and the facilitating one which implies centering on each learner (support of individual programs, design).

Largely, the conceptual model of further vocational education suggested by us is up to the outlined conceptual trends of foreign adult education development first of all in its focusing the attention on the necessity in today's postindustrial civilization conditions of a radical transition to producing the non-obvious resources (intellectual, moral and voluntary, reflexion and activity-related ones) and the newest educational technologies for obtaining them via design, organization and implementation of the unity of diverse processes and education forms in one educational space (Slobodchikov, 2009).

\section{Conclusion}

Thus, the expansion of conceptual ideas of innovation development of pedagogues' further vocational education as the most important area of continuous adult education implies considering it as a special type of education which crucially differs from today's understanding thereof in its structure, mechanisms and content, essentially and in the main messages. This is determined by the following essential characteristics: the availability of institution ensuring an efficient combination of the pedagogues' professional positions, project and network co-organization of various resources via the implementation of the project "corporate educational co-working center" and design of a special space for Meetings of cobeing.

The relevance of the question posed in the paper can be estimated by the authors-developers' ability to work out new conceptual structures of development for further vocational education and to go on to activity-based forms of transforming this educational reality. Institutionally, the implementation of conceptual trends of further vocational education system development will be ensured at the expense of activity of the federal innovation platform "Project and network institute of innovation education" which develops the "development step" logic within the context of adult education innovation development and co-ordinates works on selective creation and dissemination of event-based activity-related educational technologies for raising new professionals in the regional educational space.

\section{References}

Barmin, N.Yu., Ignatieva, G.A. (2012). Federalnaya innovatsionnaya ploshchadka Ministerstva obrazovaniya i nauki RF "Proektnosetevoy institut innovatsionnogo obrazovaniya" [Federal innovation platform of the RF Ministry of education and science "Project and network institute of innovation education"]. Information materials for the poster report. Nizhny Novgorod: Nizhegorodskij institut razvitija obrazovanija.

Habermas, J. (1987). The Theory of Communicative Action. Cambridge: Polity.

Ignatieva, G.A. (2005). Deyatelnostnoe soderzhanie professionalnogo razvitiya pedagoga $v$ sisteme postdiplomnogo obrazovaniya [Activity-based content of professional development of a pedagogue within the system of post-diploma education]. Monografija. Nizhny Novgorod: NGC. 
Kravchenko, V.V. (2012). Sopostavitelniy analiz otechestvennogo i zapadnoevropeiskogo dopolnitelnogo professionalnogo obrazovaniya [A comparative analysis of Russian and West European further vocational education]. Aftoreferat dissertacii kandidata pedagogicheskih nauk. Moskva.

Mezirov, J. (2000). Learning as Transformation: Critical Perspectives on a Theory in Progress. San Francisco: Jossey Bass.

Mitina, A.M. (2005). Stanovlenie i razvitie dopolnitelnogo obrazovaniya vzroslykh za rubezhom: kontseptualniy analiz [The rise and development of adult further education abroad: a conceptual analysis]. Aftoreferat dissertacii doktora pedagogicheskih nauk. Volgograd: Volgogradskij gosudarstvennyj pedagogicheskij universitet.

Newman, M. (2014) Transformative Learning: Mutinous Thoughts Revisited. Adult Education Quarterly, 64, 345-355.

Nicolaides, A. (2015) Generative Learning: Adults Learning Within Ambiguity. Adult Education Quarterly, 65, 179-195.

Privetkin, A.A., Privetkina, L.F. (2008). Posloynye modeli. Kniga 1: Nazad k sistemnomu podkhodu [Layered models. Book 1: Back to the systemic approach]. Moskva: Litera.

Slobodchikov, V.I. (2009). Antropologhicheskaya perspektiva otechestvennogo obrazovaniya [An anthropological perspective of Russian education]. Ekaterinburg: Izdatel'skij otdel Ekaterinburgskoj eparhii.

Samaroo S., Cooper, E., Green, T. (2013). Pedandragogy: A way forward to self-engaged learning. New Horizons in Adult Education and Human Resource Development, Vol. 25, Is. 3, 76-90.

Stein, D.S. (2014). Establishing conceptual boundaries: What is an adult education project, promise and practice. New Horizons in Adult Education and Human Resource Development. Vol. 26, Is. 1, 22-32. 